\title{
Clinical Signs and Laboratory Parameters as Predictors of Mortality among Hospitalized Human Immunodeficiency Virus-Infected Adult Patients at Tertiary Hospital in Surabaya
}

\author{
Rentha Monica Simamora ${ }^{1,2}$, Muhammad Vitanata Arfijanto ${ }^{1 *}$, Musofa Rusli ${ }^{1}$, Budi Utomo ${ }^{3}$, Cennikon Pakpahan ${ }^{4}$, \\ Garry Prasetyo Adi $^{1}$ D \\ ${ }^{1}$ Department of Internal Medicine, Faculty of Medicine, Airlangga University, Soetomo General Teaching Hospital, Surabaya, \\ Indonesia; ${ }^{2}$ Department of Internal Medicine, Dr. Kanudjoso Djatiwibowo General Hospital, Balikpapan, Indonesia; ${ }^{3}$ Department \\ of Public Health and Preventive Medicine, Faculty of Medicine, Airlangga University, Surabaya, Indonesia; ${ }^{4}$ Department of \\ Biomedical Sciences, Andrology Study Program, Faculty of Medicine, Airlangga University, Surabaya, Indonesia
}

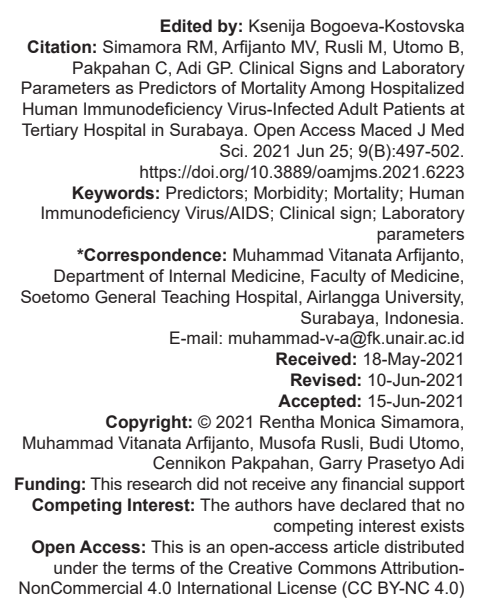

\section{Abstract}

BACKGROUND: The morbidity and mortality rates due to human immunodeficiency virus (HIV) infection are still high despite various and advanced efforts in the management given for HIVIAIDS patients.

AIM: This study proposed that clinical signs and laboratory parameters could be expected to predict the patient's mortality.

METHODS: This retrospective study was done by collecting 408 medical records of adult HIVIAIDS inpatients at a tertiary hospital in Surabaya from January 1, 2017, to December 31, 2019. Bivariate analysis using Chi-square test was carried out on nine variables, which were Glasgow Coma Scale (GCS) $<15$, hypotension, $\mathrm{PaO} / \mathrm{FiO}<400 \mathrm{mmHg}$ elevated liver enzymes, hemoglobin levels $<10 \mathrm{mg} / \mathrm{dl}$, platelet count $<150,000 / \mathrm{mm}^{3}$, eGFR $<60 \mathrm{ml} / \mathrm{min} / 1.73 \mathrm{~m}^{2}$, albumin levels $<3.5 \mathrm{mg} / \mathrm{dl}$, and body mass index (BMI) $<18.5 \mathrm{~kg} / \mathrm{m}^{2}$. Variables which met the criteria would be included in the multivariate analysis using logistic regression.

RESULTS: Based on bivariate analysis, mortality was found to be significantly associated with $\mathrm{GCS}<15$, hypotension, $\mathrm{PaO} / \mathrm{FiO}_{2}$, elevated liver enzymes, platelet count $<100,000 \mathrm{~mm}^{3}$, eGFR $<60 \mathrm{ml} / 1.73 \mathrm{~kg} / \mathrm{m}^{2}$, albumin levels $<3.5 \mathrm{mgdl}$, and $\mathrm{BMl}<18.5 \mathrm{~kg} / \mathrm{m}^{2}$. However, based on multivariate analysis, there were five variables which were found to be able to independently predict the patients' mortality, those were GCS <15 (OR 11.625), hypotension (OR 6.062) $\mathrm{PaO}_{2} / \mathrm{FiO}_{2}<400 \mathrm{mmHg}$ (OR 7.794), eGFR <60 ml/min/1.73 m² (OR 2.646), and albumin levels <3.5 mg/dl (OR 4.091). CONCLUSION: GCS <15, hypotension, $\mathrm{PaO}_{2} / \mathrm{FiO}_{2}<400 \mathrm{mmHg}$, eGFR $<60 \mathrm{ml} / 1.73 \mathrm{~g} / \mathrm{m}^{2}$, and albumin levels $<3.5 \mathrm{mg} / \mathrm{dl}$ were found as the independent risk factors which could predict the hospitalized HIV/AIDS patients mortality.

\section{Introduction}

Human immunodeficiency virus (HIV) is a retrovirus that attacks human immune cells, especially CD4 $\mathrm{T}$ cells, resulting the decreasing of the number of CD4 $\mathrm{T}$ cells which then can cause the weakening of body's immune system [1]. HIV can directly damage body's tissues and organs through an inflammatory process that causes organ dysfunction and leads to mortality. Heretofore, HIV/ AIDS has been becoming a global health problem with a high mortality rate and increasing number of sufferers every year [2], [3].

There have been various studies conducted to deepen the understanding of the characteristics and predictor factors of HIV-infected adult people's mortality. Some mortality predictors reported were platelets, glomerular filtration rate, liver function, serum albumin, CD4 values, and body mass index (BMI) [4], [5], [6]. The previous retrospective and prospective studies showed a variety of data relating to the characteristics of the research subject, socioeconomic conditions, and the length of the study conducted [7], [8], [9], [10].

Studies discussing about predictors of mortality among HIVIAIDS patients in Indonesia are still limited, whereas knowing the characteristics and factors that influence mortality is very important to improve medical interventions for HIVIAIDS patients. Therefore, this study was aimed to determine the characteristics and factors that could predict the HIV/ AIDS patients' mortality using simple parameters through clinical signs and laboratory examinations that have been routinely carried out since the beginning of the patient hospitalization. 


\section{Methods}

\section{Study design and population}

This research was conducted at a tertiary referral hospital in Surabaya, the capital of the province of East Java which has the highest number of HIVIAIDS sufferers in Indonesia. This study was a retrospective study done by collecting the medical record data which was obtained using systematic sampling from January 1, 2017, to December 31, 2019. The inclusion criteria included medical record of men and women inpatients aged $\geq 18$ years who have been diagnosed with HIVIAIDS. The HIVIAIDS diagnosis was obtained from the ICD coding listed on the medical resume. Some data which were excluded in this study were including medical records of HIVIAIDS patients who discharged at their own request, patients who had traumatic brain injury, patients who had organ dysfunction before being diagnosed with HIVIAIDS, patients who had hematological disorders before being diagnosed with HIVIAIDS, patients diagnosed with cancer that was not related to HIVIAIDS, the pregnant patients, the missing data, the incomplete data, as well as the corrupt data.

\section{Data collection}

The data were collected using a data recording form which contained the characteristics and variables of the research. Characteristics of the research's subjects were in the form of demographic and clinical data. The demographic data included the patient's age, gender, place of residence, marital status, education level, HIV risk factors, and length of the hospital stay. Moreover, the clinical data included HIV clinical stage according to the WHO, ART therapy status, Glasgow Coma Scale (GCS), $\mathrm{PaO}_{2} / \mathrm{FiO}_{2}$ ratio, blood pressure, SGOT level, SGPT level, creatinine level, glomerular filtration rate, hemoglobin level, platelet count, serum albumin level, and BMI.

The independent variables in this study were GCS <15, hypotension, $\mathrm{PaO}_{2} / \mathrm{FiO}_{2}<400 \mathrm{mmHg}$, elevated liver enzymes, hemoglobin levels $<10 \mathrm{mg} / \mathrm{dl}$, platelet counts $<150.000 / \mathrm{mm}^{3}$, eGFR $<60 \mathrm{ml} / \mathrm{min} / 1.73 \mathrm{~m}^{2}$, albumin levels $<3.5 \mathrm{mg} / \mathrm{dl}$, and BMI $<18.5 \mathrm{~kg} / \mathrm{m}^{2}$. Hypotension was defined as systolic blood pressure $<100 \mathrm{mmHg}$ or diastolic blood pressure $<60 \mathrm{mmHg}$. Elevated liver enzymes were defined as SGOT levels with values above $50 \mu / L$ or SGPT levels with values above $70 \mu / L$ [11]. This study used the CKD-EPI formula for the glomerular filtration rate. Many studies suggested that the CKD-EPI formula was more preferable than MDRD and CG for calculating the glomerular filtration rate in the HIV patient population. The CKD-EPI formula did not require any information regarding body weight, unlike CG which used to bias the results of glomerular filtration rate [10], [12], [13].

\section{Results}

In this study, most of the HIVIAIDS patients hospitalized were male with a total of 274 people (67.2\%). Furthermore, the female patients were 134 people or $32.8 \%$ of total data gained. In terms of age, it was found that the age ranged from 19 years old for the youngest to 70 years old for the eldest. Moreover, data of the patients' marital status were recorded as followed: 204 patients $(50 \%)$ were married, 158 patients $(38.7 \%)$ were single, and 46 patients $(11.3 \%)$ were widowers or widows. In addition, most of the patients, which were $87.5 \%$ of total data or 357 patients to be exact, had high school education background.

The average length of HIVIAIDS patient's the hospital stay in this study was 4 days, with 1 day for the shortest treatment duration and 54 days for the longest one. In terms of transmission risk factors, there were 81 patients $(19.8 \%)$ heterosexual risk, which was the highest risk factor in this study according to the data which has been collected. Most of the patients, specifically 390 patients (95.6\%) were domiciled in Surabaya, while only 18 patients $(4.4 \%)$ were domiciled outside Surabaya. Based on further data from 408 patients who underwent the treatment, it was known that the mortality rate was $31.1 \%$ (127/408).

The clinical characteristics used in this study included ART therapy status, the WHO clinical stage, GCS, $\mathrm{PaO}_{2} / \mathrm{FiO}_{2}$ ratio, systolic and diastolic blood pressure, eGFR, SGOT, SGPT, hemoglobin, platelets, albumin, and BMI. These clinical characteristics are shown in Table 1.

From the medical record data collected, it was known that 207 patients $(50.7 \%)$ were on ART therapy, 173 patients $(42.4 \%)$ had never received ART treatment, and 28 patients (6.9\%) stopped taking ART treatment. Most of the subjects in this study, as many as 299 patients (73.3\%), were at Stage 4 based on the WHO clinical stage. A total of 322 patients $(78.9 \%)$ had a GCS of 15 . The data of $\mathrm{PaO}_{2} / \mathrm{FiO}_{2}$ ratio showed the ratio value of $\geq 400$ in 286 patients $(70.1 \%)$ and $<400$ in 122 patients (29.9\%). As many as 322 patients $(78.9 \%)$ had systolic blood pressure of $\geq 100 \mathrm{mmHg}$. Moreover, most of the patients had diastolic blood pressure of $\geq 60 \mathrm{mmHg}$, while 46 patients $(11.3 \%)$ had diastolic blood pressure below $60 \mathrm{mmHg}$.

Based on the obtained data, there were 312 patients $(76.5 \%)$ who had eGFR $\geq 60 \mathrm{ml} / \mathrm{min} / 1.73 \mathrm{~m}^{2}$. The AST data showed that 199 patients (48.8\%) had AST $\leq 50 \mu / L$, which was almost the same as those with AST $>50 \mu / L$, specifically 209 patients $(51.2 \%)$. The SGPT data reported that most patients had SGPT values $\leq 70 \mu / L$, specifically 332 patients (81.4\%). As for the hemoglobin data, there was no significant difference between the ones who had $\mathrm{Hb} \geq 10 \mathrm{mg} / \mathrm{dl}$ and the ones 


\section{Table 1: Clinical characteristics}

\begin{tabular}{|c|c|c|c|}
\hline Characteristics & $\mathrm{n}$ & $\%$ & Result \\
\hline \multicolumn{4}{|l|}{ ART therapy status } \\
\hline Naive & 173 & 42.4 & \\
\hline Receiving ART & 207 & 50.7 & \\
\hline Loss to follow-up & 28 & 6.9 & \\
\hline \multicolumn{4}{|l|}{ WHO clinical stage } \\
\hline Stage 1 & 0 & 0 & \\
\hline Stage 2 & 0 & 0 & \\
\hline Stage 3 & 109 & 26,7 & \\
\hline Stage 4 & 299 & 73,3 & \\
\hline \multicolumn{4}{|l|}{ GCS } \\
\hline $\mathrm{GCS}=15$ & 322 & 78.9 & \\
\hline GCS $<15$ & 86 & 21.1 & \\
\hline \multicolumn{4}{|l|}{$\mathrm{PaO}_{2} / \mathrm{FiO}_{2}$} \\
\hline $\mathrm{PaO}_{2} / \mathrm{FiO}_{2}^{2} \geq 400$ & 286 & 70.1 & \\
\hline $\mathrm{PaO}_{2}^{2} / \mathrm{FiO}_{2}^{2}<400$ & 122 & 29.9 & \\
\hline \multicolumn{4}{|l|}{ Systolic blood pressure } \\
\hline$\geq 100 \mathrm{mmHg}$ & 322 & 78.9 & \\
\hline$<100 \mathrm{mmHg}$ & 86 & 21.1 & \\
\hline \multicolumn{4}{|l|}{ Diastolic blood pressure } \\
\hline$\geq 60 \mathrm{mmHg}$ & 362 & 88.7 & \\
\hline$<60 \mathrm{mmHg}$ & 46 & 11.3 & \\
\hline \multicolumn{4}{|l|}{ eGFR } \\
\hline eGFR $\geq 60 \mathrm{ml} /$ menit $/ 1.73 \mathrm{~m}^{2}$ & 312 & 76.5 & \\
\hline eGFR $<60 \mathrm{ml} / \mathrm{menit} / 1.73 \mathrm{~m}^{2}$ & 96 & 23.5 & \\
\hline \multicolumn{4}{|l|}{ SGOT } \\
\hline SGOT $\leq 50 \mu / L$ & 199 & 48.8 & \\
\hline SGOT $>50 \mu / L$ & 209 & 51.2 & \\
\hline \multicolumn{4}{|l|}{ SGPT } \\
\hline $\mathrm{SGPT} \leq 70 \mu / \mathrm{L}$ & 332 & 81.4 & \\
\hline SGPT $>70 \mu / L$ & 76 & 18.6 & \\
\hline \multicolumn{4}{|l|}{ Hemoglobin } \\
\hline $\mathrm{Hb} \geq 10 \mathrm{mg} / \mathrm{dl}$ & 206 & 50.5 & \\
\hline $\mathrm{Hb}<10 \mathrm{mg} / \mathrm{dl}$ & 202 & 49.5 & \\
\hline \multicolumn{4}{|l|}{ Platelet count } \\
\hline$\geq 150,000 / \mathrm{mm}^{3}$ & 323 & 79.2 & \\
\hline$<150,000 / \mathrm{mm}^{3}$ & 85 & 20.6 & \\
\hline \multicolumn{4}{|l|}{ Albumin levels } \\
\hline$\geq 3.5 \mathrm{mg} / \mathrm{dl}$ & 154 & 37.7 & \\
\hline$<3.5 \mathrm{mg} / \mathrm{dl}$ & 254 & 62.3 & \\
\hline \multicolumn{4}{|l|}{ BMI } \\
\hline $\mathrm{BMI} \geq 18.5 \mathrm{~kg} / \mathrm{m}^{2}$ & 205 & 50.2 & \\
\hline $\mathrm{BMI}<18.5 \mathrm{~kg} / / \mathrm{m}^{2}$ & 203 & 49.8 & \\
\hline
\end{tabular}

who had $\mathrm{Hb}<10 \mathrm{mg} / \mathrm{dl}$. There were at least 206 patients (50.5\%) who had $\mathrm{Hb} \geq 10 \mathrm{mg} / \mathrm{dl}$ and 202 patients $(49.5 \%)$ who had $\mathrm{Hb}<10 \mathrm{mg} / \mathrm{dl}$. In addition, most of the patients, specifically 323 patients $(79.2 \%)$ had $\geq 150,000$ platelet count. Moreover, there were 254 patients $(62.3 \%)$ who had an albumin value $<3.5 \mathrm{mg} / \mathrm{dl}$ and 205 patients $(50.2 \%)$ had a BMI $\leq 18.5 \mathrm{~kg} / \mathrm{m}^{2}$.

The bivariate analysis in this study used Chi-square analysis in which if $p<0.05$, the variable would be feasible to be included in the multivariate analysis. From the results of the bivariate analysis, there were eight variables that had a significant correlation with the HIVI AIDS patients' mortality, namely, GCS $<15(p=0.000)$, the ratio of $\mathrm{PaO}_{2} / \mathrm{FiO}_{2}(p=0.000)$, hypotension $(p=0.000)$, eGFR $<60 \mathrm{ml} / \mathrm{min} / 1.73 \mathrm{~m}^{2}(p=0.000)$, platelet count $<150.000 \mathrm{~mm}^{3}$ ( $\left.p=0.012\right)$, albumin level $<3.5 \mathrm{mg} / \mathrm{dl}$ ( $p$ $=0.000)$, and BMI $\leq 18.5 \mathrm{~kg} / \mathrm{m}^{2}(p=0.000)$. These eight variables would be included in the multivariate analysis to see which variable was dominant in influencing the hospitalized HIVIAIDS patients' mortality.

Multivariate analysis in this study used logistic regression analysis. The multivariate analysis which showed significant independent variables on the HIV/ AIDS patients' mortality in this study was including GCS $<15$ (OR 11.625), $\mathrm{PaO}_{2} / \mathrm{FiO}_{2}<400 \mathrm{mmHg}$ (OR 7.794), hypotension (OR 6.062 ), eGFR $<60 \mathrm{ml} / \mathrm{min} / 1.73 \mathrm{~m}^{2}$ (OR 2.646), and albumin levels $<3.5 \mathrm{mg} / \mathrm{dl}$ (OR 4.091). These bivariate analysis and multivariate analysis are shown in Table 2.
Table 2: Analysis univariate and multivariate

\begin{tabular}{|c|c|c|c|c|}
\hline \multirow[t]{2}{*}{ Variable } & \multicolumn{2}{|l|}{ Univariate } & \multicolumn{2}{|l|}{ Multivariate } \\
\hline & $\overline{\mathrm{OR}}(95 \% \mathrm{Cl})$ & p-value & $\overline{\mathrm{OR}}(95 \% \mathrm{Cl})$ & p-value \\
\hline GCS $<15$ & $11.960(6.851-20.878)$ & 0.000 & $11.625(5.410-24.981)$ & 0.000 \\
\hline $\mathrm{PaO}_{2} / \mathrm{FiO}_{2}<400 \mathrm{mmHg}$ & 11.705 (7.114-19.259) & 0.000 & $7.794(4.063-14.950)$ & 0.000 \\
\hline Hypotension & 12.738 (7.259-22.240) & 0.000 & $6.062(2.980-12.329)$ & 0.000 \\
\hline eGFR $<60 \mathrm{ml} / \mathrm{min} / 1.73 \mathrm{~m}^{2}$ & $3.317(2.061-5.340)$ & 0.000 & $2.646(1.314-5.328)$ & 0.008 \\
\hline $\begin{array}{l}\text { Elevated transaminase } \\
\text { enzyme }\end{array}$ & $3.216(2.051-5.043)$ & 0.000 & $1.824(0.946-3.516)$ & 0.104 \\
\hline Hemoglobin $<10 \mathrm{mg} / \mathrm{dl}$ & $1.452(0.952-2.213)$ & 0.082 & & \\
\hline Platelet count & $1.873(1.143-3.069)$ & 0.012 & & \\
\hline$<150,000 / \mathrm{mm}^{3}$ & & & & \\
\hline Albumin levels $<3.5 \mathrm{mg} / \mathrm{dl}$ & $5.680(3.274-9.852)$ & 0.000 & $4.091(1.846-9.070)$ & 0.001 \\
\hline $\mathrm{BMI}<18.5 \mathrm{~kg} / \mathrm{m}^{2}$ & $2.940(1.891-4.571)$ & 0.000 & $1.738(0.919-3.264)$ & 0.078 \\
\hline
\end{tabular}

\section{Discussion}

Neurological disorders associated with HIVI AIDS include central nervous system infections, neoplasms, vascular complications, peripheral neuropathy, and myopathy. Various studies which have been conducted in developing countries showed that most neurological disorders occurred due to the opportunistic infections [14]. The most frequently used parameter for measuring the impaired central nervous system function is the GCS, which is a neurological scale that aims to assess a person's consciousness. Parameters of organ function disorders, such as APACHE II and SOFA score, classify the central nervous system dysfunction if the GCS is <15 [15].

In this study, GCS $<15$ was a very significant variable on the hospitalized HIVIAIDS patients' mortality (OR 1.625; Cl 95\% 5.410-24.981; $p=0.000$ ). The results of this study supported previous study's result in which the patients with GCS $<15$ had death risk of 7.84 times higher (95\% Cl 2.03-30.27) [16], [17]. The rate resulted from the previous study was lower than the research we conducted. This could be caused by the differences of the study subjects' characteristics.

Respiratory system disorders are complications which are often found in HIVIAIDS patients and cause morbidity as well as mortality. The mechanism of HIV in causing respiratory system disorders, which in this case is lung damage, is related to systemic and lungs inflammation. Other factors which also play a role in causing lung damage are direct HIV infection to the lungs, smoking, and the effect of ARVs on lung toxicity [18]. $\mathrm{PaO}_{2} / \mathrm{FiO}_{2}$ ratio is an indicator of respiratory disorders, which in this study referred to the limit according to the SOFA score. In this study, $\mathrm{PaO}_{2} / \mathrm{FiO}_{2}$ ratio had a significant correlation with the mortality of HIVIAIDS patients with an OR 7.794 (95\% Cl 4.063-14.950). A study using the $\mathrm{PaO}_{2} / \mathrm{FiO}_{2}$ ratio was also conducted by Chiliza et al. in which the subjects were HIV patients with PCP infection. In this study, the $\mathrm{PaO}_{2} / \mathrm{FiO}_{2}$ ratio was considered as a significant predictor of mortality (HR 3.8; 95\% Cl 1.68.9; $p=0.0030)$ [19]. Likewise, the similar result was also found in a study conducted by Wu et al., in which $\mathrm{PaO}_{2}<70$ as one of the mortality predictors had an HR of 7.328 (95\% Cl 3.621-14.830) on HIVIAIDS patients' mortality [20]. 
Cardiovascular dysfunction in HIVIAIDS patients can be caused by direct viral mechanisms, opportunistic infections, and the use of ART [21]. The mechanism of the HIV virus in causing myocardial damage remains unclear. However, it is suspected that there are changes in the function of Th lymphocytes which then cause severe inflammation of the myocardium [22]. Opportunistic infections caused by Toxoplasma gondii, Mycobacterium tuberculosis, and Cryptococcus neoformans are common in AIDS myocarditis [23]. Treatment with ARVs, especially for the NRTI group, causes a lot of cardiomyopathy through mitochondrial damage which eventually causes myocardial dilatation and dysfunction. Moreover, hypotension is a condition that occurs due to impaired cardiovascular function. This condition indicates the decreasing of cardiac output which can lead to impaired tissue perfusion [24]. This study found that hypotension correlated significantly with the mortality of HIVIAIDS patients by which an OR of $6.062(95 \% \mathrm{Cl}$ OR $2.980-12.329)$. These results supported previous research conducted by Bloomfield et al. which resulted IR value of 5.2 (CI 95\% 4.8-5.7) [25].

HIV-infected patients have a higher risk of developing kidney disease, terminal renal failure, and death due to kidney disease. A study carried out on $306 \mathrm{HIV} /$ AIDS patients in China found that the prevalence of kidney problems experienced by hospitalized HIVIAIDS patients reached $5.56 \%$ [26]. Disruption of kidney function in HIV/ AIDS-infected patients can be caused by acute kidney failure, HIV-associated nephropathy, and the presence of comorbid chronic kidney disease [27]. Multivariate analysis done in this study showed that impaired renal function had a significant correlation to HIVIAIDS patients' mortality with an OR $2.646(95 \% \mathrm{Cl} 1.314-5.328)$. This study supported the research conducted in Jakarta [6] as well as the research conducted by Wyatt et al. However, there was a slight difference between the result of this study and a study conducted by Wyatt et al. Categorized into acute renal failure and chronic kidney disease, Wyatt et al study stated that acute renal failure ( $\mathrm{OR}=5.84 ; 95 \% \mathrm{Cl} 5.11$ $6.65)$ possessed higher mortality risk compared to chronic kidney disease (OR=1.97\%; 95\% Cl 1.59-2.45) [28].

Reduced glomerular filtration rate is associated with the increasing of cardiovascular events causing mortality in general population. In populations with decreased glomerular filtration, there was an increase in apolipoprotein B and a decrease in apolipoprotein $\mathrm{A} 1$, which is a risk factor for coronary heart disease. It was also found that there was an increase in fibrinogen and homocysteine, as well as C-reactive protein which is associated with atherosclerosis. The atherosclerosis itself can increase the risk of cardiovascular disease in the decreased glomerular filtration population [29]. The decreasing of erythropoietin hormone can cause anemia which then results in increasing the endothelial activation and left ventricular hypertrophy. This condition can increase the cardiovascular risk which leads to morbidity and mortality [30]. Disorders of electrolytes or acid base and fluid retention in impaired kidney function can also increase the mortality risk [6].

Several studies have also tried to find a correlation between low albumin levels and mortality in HIVIAIDS patients. Some have found that hypoalbuminemia could be an independent predictor of HIVIAIDS patients' mortality. Low albumin levels $(<3.5 \mathrm{~g} /$ dl) are associated with the progression of HIV patients to AIDS [8], [28]. In subjects with CD4 <200 who had albumin levels $<3.5 \mathrm{~g} / \mathrm{dl}$, the mortality rate was 8 times higher than those with albumin levels > $3.5 \mathrm{~g} / \mathrm{dl}$ [8]. Research on the correlation between serum albumin and mortality in HIVIAIDS patients has also been conducted and showed that patients with albumin levels $<3.5 \mathrm{~g} / \mathrm{dl}$ at the beginning of ART therapy had mortality rate 4.53 times higher than the subjects who had albumin levels $>3.5 \mathrm{~g} / \mathrm{dl}(95 \% \mathrm{Cl})$ [31]. In our study, albumin levels $<3.5 \mathrm{mg} / \mathrm{dl}$ had a significant correlation with the HIVIAIDS patients' mortality (OR 4.091, 95\% CI OR 1.846-9.070). Furthermore, receiver operating characteristic (ROC) curve analysis was also performed for the hypoalbuminemia variable. Based on the analysis of the ROC curve, it was found that the area under the curve was 0.751 with $p=0.027$. The best cutoff point for albumin level to predict mortality outcome was in the value of 3.02 with sensitivity of $71.7 \%$ and specificity of $70.5 \%$ (Figure 1).

There were also some variable which showed insignificant result in multivariate analysis, those were platelet count, elevated liver enzymes, and BMI. Platelet count $<150,000 \mathrm{~mm}^{3}$ in HIVIAIDS patients causes mortality, generally due to the occurrence

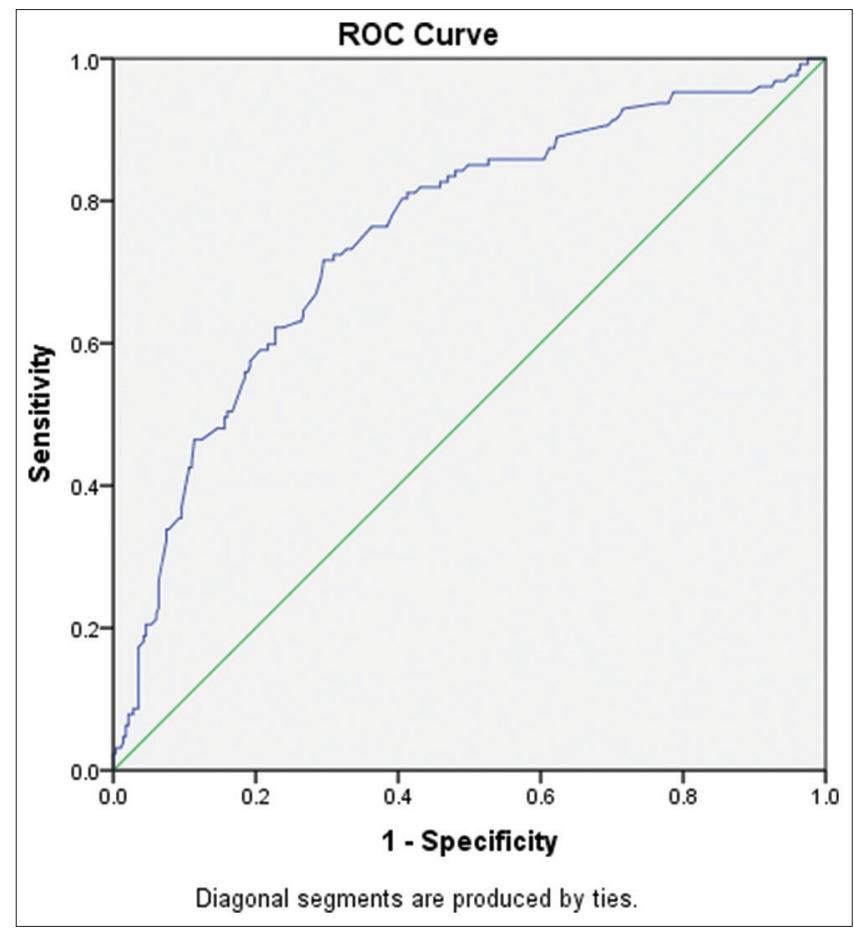

Figure 1: Receiver operating characteristic curve hypoalbuminemia to predict mortality. The best cutoff point value for albumin level for predicting the mortality outcome was 3.02 with sensitivity of $71.7 \%$ and specificity of $70.5 \%$ 
of impaired central nervous system function which caused by intracranial bleeding characterized by the GCS. Elevated liver enzymes can be associated with mortality generally through the occurrence of acute liver failure causing encephalopathy which eventually leads to impaired central nervous system function which is also characterized by GCS. BMI $<18.5 \mathrm{~kg} / \mathrm{m}^{2}$ can cause mortality due to susceptibility toward hypoalbuminemiaassociated infection, in which hypoalbuminemia itself showed a significant correlation with HIVIAIDS hospitalized patients' mortality in multivariate analysis.

\section{Conclusion}

The mortality percentage of hospitalized HIVIAIDS patients in this study was recorded at the value of $31.1 \%$. Multivariate analysis which showed GCS <15, hypotension, $\mathrm{PaO}_{2} / \mathrm{FiO}_{2}<400 \mathrm{mmHg}$, eGFR $<60 \mathrm{ml} / 1.73 \mathrm{~kg} / \mathrm{m}^{2}$, and albumin levels $<3.5 \mathrm{mg} / \mathrm{dl}$ was found as an independent risk factors for predicting the hospitalized HIVIAIDS patients' mortality. Early intervention on these significant variables is expected to be able to improve the mortality rate of hospitalized HIVIAIDS patients.

\section{Acknowledgments}

The author thanks to Inthen Firdausi Wardhani for providing language corrections to this article.

\section{References}

1. Djoerban Z, Djauzi S. HIVIAIDS di Indonesia in Buku Ajar IImu Penyakit Dalam. $6^{\text {th }}$ ed., Vol. 1. Jakarta: Balai Penerbit FKUI; 2015.

2. Japiassu AM, Amancio RT, Mesquita EC, Medeiros DM, Bernal HB, Nunes EP, et al. Sepsis is a major determinant of outcome in critically ill HIVIAIDS patients. Crit Care. 2010;14(4):R152. https://doi.org/10.1186/cc9221 PMid:20698966

3. Redig AJ, Berliner N. Pathogenesis and clinical implications of HIV-related anemia in 2013. Hematol Am Soc Hematol Educ Program. 2013;2013(1):377-81. https://doi.org/10.1182/ asheducation-2013.1.377 PMid:24319207

4. Saleri N, Capone S, Pietra V, laco G, Del Punta V, Rizzi M, et al. Outcome and predictive factors of mortality in hospitalized HIVpatients in burkina faso. Infection. 2009;37(2):142-7. https://doi. org/10.1007/s15010-008-7406-7

PMid:19169635

5. Rubaihayo J, Tumwesigye NM, Konde-lule J, Makumbi F,
Nakku EJ, Wamani $\mathrm{H}$, et al. Trends and predictors of mortality among HIV positive patients in the era of highly active antiretroviral therapy in Uganda. Infect Dis Rep. 2015;7(3):6673. https://doi.org/10.4081/idr.2015.5967

PMid:26500739

6. Puspitasari E, Yunihastuti E, Rengganis I, Rumende CM Prediktor mortalitas pasien HIVIAIDS rawat inap. J Pen Dalam Indones. 2016;3(1):22-8. https://doi.org/10.7454/jpdi.v3i1.29

7. Deshwal R, Arora S. Serum alanine aminotransferase elevations in HIV positive patients on antiretroviral therapy in India. J Assoc Phys India. 2019;67(3):67-70.

PMid:31304710

8. Feldman JG, Burns DN, Stephen J, Bacchetti P, Cohen M, Anastos $\mathrm{K}$, et al. Serum albumin as a predictor of survival in HIV-infected women in the women's interagency HIV study. AIDS. 2000;14(7):863-70. https://doi. org/10.1097/00002030-200005050-00013 PMid:10839595

9. Hu W, Jiang H, Chen W, He S, Deng B, Wang W. Malnutrition in hospitalized people living with HIVIAIDS : Evidence from a cross-sectional study from Chengdu, China. Asia Pac J Clin Nutr. 2011;20(4):544-50.

PMid:22094839

10. Ibrahim F, Hamzah L, Jones R. Baseline kidney function as predictor of mortality and kidney disease progression in HIVpositive patients. Am J Kidney Dis. 2012;60(4):539-47. https:// doi.org/10.1053/j.ajkd.2012.03.006

PMid:22521282

11. Dusingize JC, Hoover DR, Shi Q, Mutimura E, Rudakemwa E, Ndacyayisenga $\mathrm{V}$, et al. Association of abnormal liver function parameters with HIV serostatus and CD4 count in antiretroviralnaïve rwandan women. AIDS Res Hum Retroviruses. 2015;31(7):723-30. https://doi.org/10.1089/aid.2014.0170 PMid:25924728

12. Owiredu WK, Quaye L, Amidu N, Addai-Mensah O. Renal insufficiency in Ghanaian HIV infected patients: Need for dose adjustment. Afr Health Sci. 2013;13(1):101-11. https://doi. org/10.4314/ahs.v13i1.14 PMid:23658575

13. Mocroft A, Ryom L, Reiss P, Furrer H, Monforte AD, Gatell J et al. A comparison of estimated glomerular filtration rates using Cockcroft-Gault and the chronic kidney disease epidemiology collaboration estimating equations in HIV infection. HIV Med. 2014;15(3):144-52. https://doi.org/10.1111/hiv.12095 PMid:24118916

14. Mamidi A, DeSimone JA, Pomerantz RJ. Central nervous system infections in individual with HIV-1 infection. J Neurovirol. 2002;8(3):158-67. https://doi.org/10.1080/13550280290049723 PMid: 12053271

15. Grmec S, Gasparovic V. Comparison of APACHE II, MEES and Glasgow coma scale in patients with nontraumatic coma for prediction of mortality. Crit Care. 2000;5(1):19-23. https://doi. org/10.1186/cc973

PMid: 11178221

16. Lee $\mathrm{Y}$, Wang J, Sun H, Chen Y. Comparisons of clinical features and mortality of cryptococcal meningitis between patients with and without human immunodeficiency virus infection. J Microbiol Immunol Infect 2011;44(5):338-45. https://doi.org/10.1016/j. jmii.2010.08.011

PMid:21524972

17. Pecego AC. Amancio RT, Ribeiro C, Mesquita EC, Medeiros DM, Cerbino $\mathrm{J}$, et al. Six-month survival of critically ill patients with HIV--related disease and tuberculosis: A retrospective study. BMC Infect Dis. 2016;6:270. https://doi.org/10.1186/ s12879-016-1644-6 
18. Cribbs SK, Crothers K, Morris A. Pathogenesis of HIVrelated lung disease: Immunity, infection, and inflammation. Physiol Rev. 2020;100(2):603-32. https://doi.org/10.1152/ physrev.00039.2018

\section{PMid:31600121}

19. Chiliza N, Du Toit M, Wasserman S. Outcomes of HIV-associated pneumocystis pneumonia at a South African referral hospital. PLoS One. 2018;13(8):e0201733. https://doi.org/10.1371/ journal.pone.0201733

PMid:30071089

20. Wu L, Zhang S, Wang Y, Hao Y, Wang F, Gao G, et al. A model to predict in-hospital mortality in HIVIAIDS patients with pneumocystis pneumonia in China: The clinical practice in real world. Biomed Res Int 2019;2019:6057028. https://doi. org/10.1155/2019/6057028

PMid:30906778

21. Ho JE, Hsue PY. Cardiovascular manifestations of HIV infection. Heart. 2009;95(14):1193-202. https://doi.org/10.1136/ hrt.2008.161463

PMid: 19564432

22. Moroni M, Antinori S. HIV and direct damage of organs: Disease spectrum before and during the highly active antiretroviral therapy era. AIDS. 2003;17(1):S51-64. https://doi. org/10.1097/00002030-200304001-00008 PMid:12870531

23. Ntusi NA. HIV and myocarditis. Curr Opin HIV AIDS. 2017;12(6):561-5. https://doi.org/10.1097/ coh. 0000000000000416 PMid:28832366

24. Cheitlin MD. In: Basow DS, editor. Cardiac Involvement in HIVinfected Patients. $2^{\text {nd }}$ ed. Waltham, MA: UptoDate; 2010.

25. Bloomfield GS, Hogan JW, Keter A, Holland TL, Sang E, Kimaiyo $\mathrm{S}$, et al. Blood pressure level impacts risk of death among HIV seropositive adults in Kenya: A retrospective analysis of electronic health records. BMC Infect Dis. 2014;14:284. https://doi.org/10.1186/1471-2334-14-284

\section{PMid:24886474}

26. Sun C, Wen Y, Liu S, Cui W, Zhou Y, Deng, B, et al. Prevalence of ginjal impairment among HIV positive patients hospitalized in the first hospital of China medical university. Int J Clin Exp Med. 2018;11(8):8622-862.

27. Wyatt CM. Kidney disease and HIV infection. Top Antivir Med. 2017;25(1):13-6.

PMid:28402929

28. Wyatt CM, Klotman PE, Bronfman S, D'Agati VD. HIV-associated nephropathy: Clinical presentation, pathology, and epidemiology in the era of antiretroviral therapy. Semin Nephrol. 2008;28(6):51322. https://doi.org/10.1016/j.semnephrol.2008.08.005 PMid:19013322

29. Munthner P, Hamm L, Kusek JW, Chen J, Whelton PK $\mathrm{He}$ J. The prevalence of nontraditional risk factors for coronary heart disease in patients with chronic kidney disease. Ann Intern Med. 2004;140(1):9-17. https://doi. org/10.7326/0003-4819-140-1-200401060-00006 PMid:14706967

30. George E, Lucas GM, Nadkarni GN, Fine DM, Moore R, Atta MG. Kidney function and the risk of cardiovascular events in HIV-1 infected patients. AIDS. 2010;24(3):387-94. https://doi. org/10.1097/qad.0b013e3283359253

PMid:20019575

31. Sudfeld CR, Isanaka S, Aboud S, Mugusi FM, Wang M, Chalamilla GE, et al. Association of serum albumin concentration with mortality, morbidity, CD4 T-cell reconstitution among tanzanians initiatin antiretroviral therapy. J Infect Dis. 2013;207(9):1370-8.

PMid:23319741 